\title{
Response of Paenibacillus polymyxa to Iron: Alternations in Cellular Chemical Composition and the Production of Fusaricidin Type Antimicrobial Compounds
}

\author{
Waseem Raza, Wu Hongsheng and Shen Qirong* \\ College of Resource and Environmental Sciences; Nanjing Agriculture University; n.1; Weigang Road; Nanjing, \\ 210095; Jiangsu Province - PR - China
}

\begin{abstract}
In this work, growth, cellular chemical composition and production of fusaricidin type antimicrobial compounds by $P$. polymyxa SQR-21 were compared in tryptone broth supplemented with four concentrations of iron (25, 50, 100 and 200 $\mu M)$. The data revealed that the growth of P. polymyxa SQR-21 was increased by 3-8\% with the increase in concentration of ferric ion $\left(\mathrm{Fe}^{3+}\right)$. The production of fusaricidin type compounds was increased by 33-49\% only up to $50 \mu \mathrm{MFe} \mathrm{F}^{3+}$ and the highest level of $\mathrm{Fe}^{3+}$ was inhibitory. Increase in the liquid culture $\mathrm{Fe}^{3+}$ concentration increased the intracellular protein (2\%), intracellular carbohydrate (14\%), extracellular protein $(7 \%)$ and polysaccharide contents $(18 \%)$ while the intracellular lipid contents were increased (11\%) only up to $50 \mu \mathrm{M} \mathrm{Fe} e^{3+}$. In addition, the regulatory effects of $\mathrm{Fe}^{3+}$ were also reflected by the increase in total RNA contents and relative expression of the fusaricidin synthetase gene (FusA) by 313 and $35-56 \%$, respectively, up to $50 \mu \mathrm{MFe}^{3+}$, after that a continuous decrease was observed.
\end{abstract}

Key words: Chemical composition, Fusaricidin, Iron; Paenibacillus polymyxa, RNA

\section{INTRODUCTION}

The Paenibacillus polymyxa, formerly Bacillus polymyxa (Ash et al., 1991), is a Gram-positive, aerobic or facultative anaerobic, rod-shaped, endospore-forming bacterium that is commonly found in many mineral deposits and in the rhizosphere (Raza et al., 2009; Zhang et al., 2008). $P$. polymyxa has become important biological control microorganism and has been top ranked among the applied microorganisms in commerce by US Environmental Protection Agency (EPA) in 2002 (Bent, 2002). As a member of the rhizosphere community, $P$. polymyxa may antagonize plant pathogenic microorganisms and, therefore, minimize the damage to the roots. The bacterium has long been known for its ability to produce two groups of antimicrobial compounds. One group comprises the antibiotics, active against bacteria, such as polymyxins, polypeptins etc. (Ito and Koyama, $1972 \mathrm{a} ; 1972 \mathrm{~b})$. The other group is made up of the peptide antibiotics active against fungi and Grampositive bacteria, such as gavaserin, saltavalin and fusaricidins A, B, C, and D (Pichard et al., 1995; Beatty and Jensen, 2002). In addition, there are many reports where the nature of the inhibitory agent is undefined (Dijksterhuis et al., 1999). In this work, P. polymyxa strain SQR-21 was used, found to produce fusaricidin type of antifungal compounds, composed of a group of

*Author for correspondence: shenqirong@ njau.edu.cn 
cyclic depsipeptides with molecular masses of 883, 897, 948 and $961 \mathrm{Da}$, and an unusual15guanidino-3-hydroxypentadecanoic acid moiety bound to a free amino group (Raza et al., 2009). $P$. polymyxa SQR-21 was evaluated for all the possible antimicrobial volatile and non-volatile metabolites and it was found that this strain did not produce any volatile antimicrobial compound, except fusaricidin type antifungal compounds. The fusaricidin production was optimized under different conditions, including temperature, $\mathrm{pH}$ and $\mathrm{C}$ sources, etc. (Raza et al., 2009). The fusaricidin biosynthetic gene cluster spans $32.4 \mathrm{~kb}$, including an open reading frame and encodes a six-module nonribosomal peptide synthetase ( $\mathrm{Li}$ and Jensen, 2008). Fusaricidin has excellent germicidal activity against plant pathogenic fungi such as Fusarium oxysporum, Aspergillus niger, Aspergillus oryzae and Penicillum thomii and particularly fusaricidin B has germicidal activity against Candida albicans and Saccharomyces cerevisiae (Kajimura and Kaneda, 1997; Raza et al., 2008; Ryu et al., 2006). Fusaricidin also has excellent germicidal activity against Grampositive bacteria, including Staphylococcus aureus and Leptosphaeria maculans (Dijksterhuis et al., 1999; Beatty and Jensen, 2002). According to the recent reports on the excellent germicidal activity of fusaricidin against pathogenic Gram-positive bacteria and plant pathogenic fungi, fusaricidin seems to have great potential for industrial uses and thereby is in increasing demand. Therefore, it is desirable to find the ways to increase the production of fusaricidin.

In liquid culture, antibiotic production by many organisms is influenced by carbon and nitrogen sources, inorganic compounds and growth phase (Espeso and Penalva, 1992; Milner et al., 1995). Among these, iron has its own importance. Iron is known to be a "key" metal for secondary metabolite production in bacteria. It is perhaps the most important micronutrient used by bacteria and is required as a cofactor for a large number of enzymes and iron-containing proteins (Leong et al., 1990). The effect of iron on antibiotic production has been widely studied. In Streptomyces sp., iron is a requirement for the production of actinomycin, neomycin, streptomycin and chloramphenicol (Weinberg, 1970). An antifungal antibiotic, azasteroidal, from Geotrichum flavo-brunneum was enhanced by $10 \%$ with the addition of $0.2 \%$ iron (Boeck et al., 1975). The bacterial culture of Nocardia mediterranea A TCC 13685 was used for the production of antitubercular antibiotic rifamycin by submerged fermentation and it was observed that
$100 \mathrm{ppm}$ of iron had stimulatory effects on the rifamycin production (Mukhtiar, 2000). In addition, ferric iron (0.25-1.0 mM) enhanced zwittermicin A accumulation and disease suppression (Milner et al., 1995) and Kanosamine accumulation was enhanced by the addition of ferric iron to rich medium (Milner et al., 1996). However, there is no information regarding the effect of iron on fusaricidin production by $P$. polymyxa. A study was planned to determine the effect of ferric ion $\left(\mathrm{Fe}^{3+}\right)$ on the growth and fusaricidins production by $P$. polymyxa strain SQR21. In addition, to get more knowledge about metabolic effects of iron in $P$. polymyxa, intra and extracellular chemical composition and total RNA contents were measured and fusaricidin gene expression was evaluated by reverser transcriptase and Real Time PCR assay.

\section{MATERIAL AND METHODS}

\section{Bacteria and fungi strains}

A chitinase deficient and fusaricidin producing strain of Paenibacillus polymyxa SQR-21 and a tested pathogenic strain Fusarium oxysporum f. sp. cucumerinum ( $F$. oxysporum) were provided by the Soil-Microbe-Interaction Laboratory, Nanjing Agriculture University, Nanjing, China. The bacterial culture was maintained on potato dextrose agar (PDA) plates and was stored at $-80^{\circ} \mathrm{C}$ in tryptic soya broth (TSB) containing 20\% glycerol for further use. The fungal pathogenic strain was maintained by cultivation on PDA plates for three days at $28^{\circ} \mathrm{C}$ and then the plates were sealed with parafilm and stored at $4^{\circ} \mathrm{C}$. The pathogen was subcultured onto a fresh PDA plate after one month.

\section{Media preparation and antifungal activity assay}

Liquid-culture experiments were performed in 100 $\mathrm{ml}$ of tryptone broth (tryptone; $10, \mathrm{NaCl} ; 5$ and sucrose; $10 \mathrm{~g} / \mathrm{L} ; \mathrm{pH}$ 7.2) in $500 \mathrm{ml}$ Erlenmeyer flasks. Initial $\mathrm{Fe}^{3+}$ contents in tryptone broth were 10 $\mu \mathrm{M}$, determined by Spectra AA, 220 FS atomic absorbance spectrometry. After sterilization, the cultures were supplemented with $\mathrm{FeCl}_{3}$; four concentrations of $\mathrm{Fe}^{3+}(25,50,100$ and $200 \mu \mathrm{M})$ were considered. Each experiment had three replicates, including the control cultures without supplemented $\mathrm{Fe}^{3+}$. For the isolation of antifungal compounds, SQR-21 strain was pre-inoculated in tryptone broth overnight at $37^{\circ} \mathrm{C}$. After adding $\mathrm{FeCl}_{3}$, tryptone broth was inoculated with $100 \mu \mathrm{L}$ of over night culture of SQR-21 and incubated in a shaking 
incubator $\left(170 \mathrm{rpm}, 37^{\circ} \mathrm{C}\right)$. After four days, $\mathrm{OD}_{600}$ and $\mathrm{pH}$ were determined and liquid cultures were centrifuged at $12000 \times \mathrm{g}$ for $10 \mathrm{~min}$ to remove the cells. The supernatants were pooled and active compounds were extracted twice with an equal volume of n-butanol. The extracts were concentrated by using a rotary evaporator and the residues were dissolved in methanol. These extracts were used to determine the antifungal activity by agar diffusion assay using $F$. oxysporum as test pathogen. After three days, the inhibition zone was measured. To represent the cellular data (protein, carbohydrate, lipid and RNA contents) on dry weight basis, the dry weights of lyophilized cell pellets were measured.

\section{Cellular chemical composition}

The bacterial liquid culture samples $(2 \mathrm{ml})$ were centrifuged $(12,000 \mathrm{x} \mathrm{g})$ for $10 \mathrm{~min}$. The cell pellets were suspended in $2 \mathrm{ml}$ of deionized water for washing and then centrifuged three times. These pellets were used for the determination of total intracellular protein, carbohydrate and lipid contents separately. For total protein contents, the rinsed cells were resuspended in deionized water and incubated in $1 \mathrm{~N} \mathrm{NaOH}$ at $90^{\circ} \mathrm{C}$ for $10 \mathrm{~min}$ to solubilize cellular protein. Proteins were measured by the method of Bradford (1976) with bovine serum albumin standards ranging from $10-100 \mu \mathrm{g} / \mathrm{ml}$. Total carbohydrate contents were estimated in the rinsedcell samples by the phenol-sulfuric acid method (Dubois et al., 1956). The lipid contents of bacterial cells were calculated by the phosphoric acid-vanillin reagent method of Izard and Limberger (2003) with Triolein standards ranging from 10 to $100 \mu \mathrm{g}$. The cell-free liquid culture was used for the estimation of extracellular protein and polysaccharide (EPS) contents by the above-described methods. For EPS estimation, the liquid culture was heated to boiling for $10 \mathrm{~min}$ to release the polysaccharides attached to the cells and to inactivate polysaccharide degrading enzymes then liquid culture was cooled and centrifuged to remove the cells. Before assaying the protein, the resulting EPS solution was dialyzed using a membrane of $1000 \mathrm{MWCO}$ against ultra pure water for two days at $4{ }^{\circ} \mathrm{C}$ to remove the small molecules and entrained media residues. Protease activity of the liquid culture was assayed as described by Tseng and Mount (1974). One unit of activity was defined as the activity, which resulted an increase in OD of $0.1 \mathrm{OD}$ units per $30 \mathrm{~min}$ per $\mathrm{ml}$ of enzyme. Cellulase activity was determined by the DNS method (Berlin et al., 2005). One unit cellulase activity was defined as the amount of enzyme that produced $1 \mu \mathrm{mol}$ reduced sugar per hour.

\section{RNA extraction and primers design}

Total RNA was isolated by using the Trizol reagent method (Invitrogen ${ }^{\mathrm{TM}}$, Shanghai) according to manufacturer's instructions. To remove the contaminating DNA, 10U DNase1 (Takara, Dalian) along with 20U RNase inhibitor (Takara, Dalian) $\left(37^{\circ} \mathrm{C}, 40 \mathrm{~min}\right)$ were used in the reaction mixture of $50 \mu \mathrm{l}$ containing 20-50 $\mu \mathrm{g}$ RNA. RNA was estimated by determining the absorbance at $260 \mathrm{~nm}$. Specific primers for fusaricidin synthetase gene (fusA) (111bp) and 16S rRNA gene (16s) (210bp) were designed by using the premier 5 software (PREMIER biosoft international). The designed primers were as follows:

fusAl, 5' GCAGAGGATGATAGTGTTGGTC 3', fasA2, 5' CAGCACATCATGCGTTCC 3'.

$16 s 1,5^{\prime}$ CATTCATCGTTTACGGCGT 3' and

$16 s 2,5^{\prime}$ TGTTAATCCCGAGGCTCACT 3'.

\section{Reverse transcription and Real Time PCR assay}

For the synthesis of first stand cDNA, $3 \mu \mathrm{g}$ of total RNA, 200U of RevertAid ${ }^{\mathrm{TM}}$ M-MuLV reverse transcriptase (Fermantas), 20U RNase inhibitor (TaKaRa, Dalian), $0.2 \mu \mathrm{g}$ of Random hexamer primer and $1 \mathrm{mM}$ dNTP in the total volume of $20 \mu \mathrm{l}$ were used. RT was performed using the following parameters; $5 \mathrm{~min}$ at $65^{\circ} \mathrm{C}, 2 \mathrm{~min}$ on ice, $60 \mathrm{~min}$ at $42^{\circ} \mathrm{C}$ and $5 \mathrm{~min}$ at $95^{\circ} \mathrm{C}$. Target genes from cDNA were amplified separately using $3 \mu \mathrm{l}$ aliquots of RT product as template and $30 \mathrm{pmol}$ of each primer pair. Reaction mixtures for PCR contained 2.5 U Taq polymerase (TaKaRa, Dalian), $20 \mathrm{nmol}$ of dNTP and $100 \mathrm{nmol} \mathrm{Mg}^{2+}$. The PCR conditions were as follows; $5 \mathrm{~min}$ at $95^{\circ} \mathrm{C}, 30$ cycles; each including $30 \mathrm{~s}$ at $94^{\circ} \mathrm{C}, 30 \mathrm{~s}$ at $58^{\circ} \mathrm{C}$ and $1 \mathrm{~min}$ at $72^{\circ} \mathrm{C}$ and in the end $2 \mathrm{~min}$ at $72^{\circ} \mathrm{C}$. Amplified products were checked for band intensity and cDNA quality in $2 \%$ agarose $(w / v)$. Singleplex relative Real Time PCR was performed using an $\mathrm{iCycler}_{\mathrm{MyiQ}}^{\mathrm{TM}}$ single color Real Time PCR detection system (BioRad). Reactions were performed in a $20 \mu \mathrm{l}$ volume reaction mixture containing $1 \mathrm{mM}$ primers, $3 \mu \mathrm{cDNA}$ and $10 \mu 1$ of SYBR $^{\circledR}$ Premix Ex Taq ${ }^{\mathrm{TM}}$ (Perfect Real Time) (TaKaRa, Dalian), including TaKaRa Ex $T a q^{\mathrm{TM}} \mathrm{HS}$ and SYBR ${ }^{\circledR}$ Green I, dNTP and buffer. The PCR protocol included; $10 \mathrm{~min}$ at $95^{\circ} \mathrm{C}$ followed by 40 cycles with $95^{\circ} \mathrm{C}$ for $30 \mathrm{~s}, 58^{\circ} \mathrm{C}$ for $30 \mathrm{~s}$ and $72^{\circ} \mathrm{C}$ for $1 \mathrm{~min}$. The detection of the fluorescent product was carried out at the end of the $72^{\circ} \mathrm{C}$ 
extension period ( $2 \mathrm{~min}$ ). After the PCR, these samples were heated from 58 to $95^{\circ} \mathrm{C}$. When the temperature reached the Tm of each fragment, there was a steep decrease in fluorescence of the product. The $2 \mu \mathrm{l}$ cDNA of each treatment were mixed together to prepare relative standards. The whole experiment was repeated twice.

\section{Statistical Analysis}

For the statistical analysis, Duncan's multiple-range test was applied when one-way ANOVA revealed significant differences $(\mathrm{P} \leq 0.05)$. All the statistical analysis was performed with SPSS BASE ver.11.5 statistical software (SPSS, Chicago, IL).

\section{RESULTS}

The results regarding the effect of different ferric ion concentrations $(0,25,50,100,200 \mu \mathrm{M}$ $\mathrm{Fe}^{3+}$ ) on optical density (OD) and antifungal activity (Fig. 1) revealed that OD of liquid culture $(\mathrm{LSD}=0.09)$ of $P$. polymyxa $\mathrm{SQR}-21$ and antifungal activity (LSD $=1.80$ ) against $F$. oxysporum were increased by increasing the concentration of $\mathrm{Fe}^{3+}$ after four days incubation. The maximum OD was determined at $200 \mu \mathrm{M}$ $\mathrm{Fe}^{3+}$ while maximum antifungal activity was determined at $50 \mu \mathrm{M} \mathrm{Fe} e^{3+}$. The increase in $\mathrm{OD}$ over untreated control was $3,4,5$ and $8 \%$ at 25 , $50,100,200 \mu \mathrm{M} \mathrm{Fe}^{3+}$, respectively.

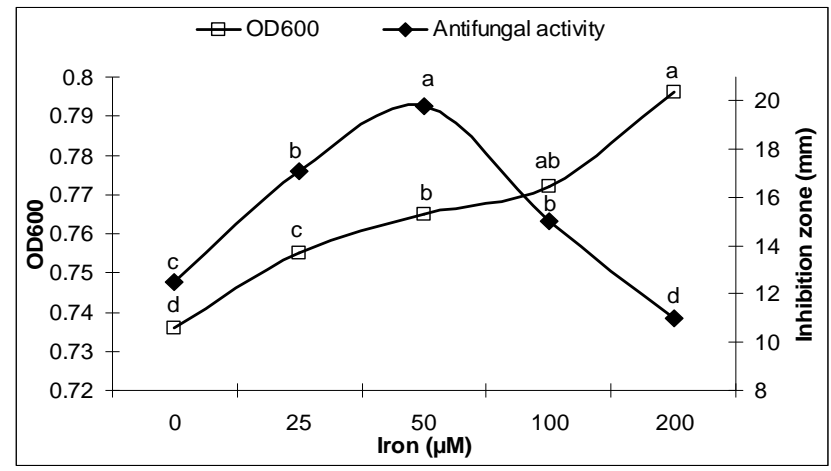

Figure 1 - Effect of different $\mathrm{Fe}^{3+}$ concentrations $\left(0,25,50,100\right.$ and $\left.200 \mu \mathrm{M} \mathrm{Fe}{ }^{3+}\right)$ on $\mathrm{OD}_{600}$ and antifungal activity of $P$. polymyxa SQR-21 against Fusarium oxysporum after four days incubation. Letters indicate a significant difference with means of three replicates at $\mathrm{P} \leq 0.05$ level.

The increase in the antifungal activity over untreated control was 33,49 and $25 \%$ at 25,50 and $100 \mu \mathrm{M} \mathrm{Fe}^{3+}$, respectively while at the highest level of $\mathrm{Fe}^{3+}(200 \mu \mathrm{M}), 12 \%$ decrease in antifungal activity was measured. Initially, the tryptone medium has $\mathrm{pH} 7.2$ but after four days incubation, $P$. polymyxa cells increased the $\mathrm{pH}$ of liquid culture by $15-16 \%$ at all levels of $\mathrm{Fe}^{3+}(\mathrm{LSD}=$ $0.56)$ and among all levels of $\mathrm{Fe}^{3+}$, the differences were non-significant (Fig. 2). The liquid culture, used to extract the antifungal compounds and to measure the OD, was also used to estimate the extra and intracellular chemical composition.

The data regarding the intracellular chemical composition depicted that increase in the concentration of $\mathrm{Fe}^{3+}$ in the liquid culture increased the intracellular protein $(\mathrm{LSD}=3.49)$ and carbohydrate contents (LSD $=7.02)$ (Fig. 3) while the intracellular lipid contents $(\mathrm{LSD}=5.67)$
(Fig. 4) were increased only at 25 and $50 \mu \mathrm{M} \mathrm{Fe}^{3+}$. The increase in intracellular protein contents was $0.6,1$ and $2 \%$ at $25,50,100 \mu \mathrm{M} \mathrm{Fe}^{3+}$, respectively and in the intracellular carbohydrate contents, the increase was $1,5,10$ and $14 \%$ as compared with control, at $25,50,100,200 \mu \mathrm{M} \mathrm{Fe}^{3+}$, respectively. The increase in the intracellular lipid contents at 25 and $50 \mu \mathrm{M} \mathrm{Fe}^{3+}$ was 11 and $2 \%$, respectively while decrease in the lipid contents was 4 and $12 \%$ at 100 and $200 \mu \mathrm{M} \mathrm{Fe}^{3+}$, respectively. All the $\mathrm{Fe}^{3+}$ levels showed more protein contents over control but with the increase in $\mathrm{Fe}^{3+}$ concentration from 100 to $200 \mu \mathrm{M}$, decrease in the intracellular protein contents was measured.

The data regarding the extracellular chemicalcomposition revealed that all levels of $\mathrm{Fe}^{3+}$ increased the extracellular protein $(\mathrm{LSD}=$ 7.08) (Fig. 5) and EPS contents (LSD = 39.19) (Fig. 5). 


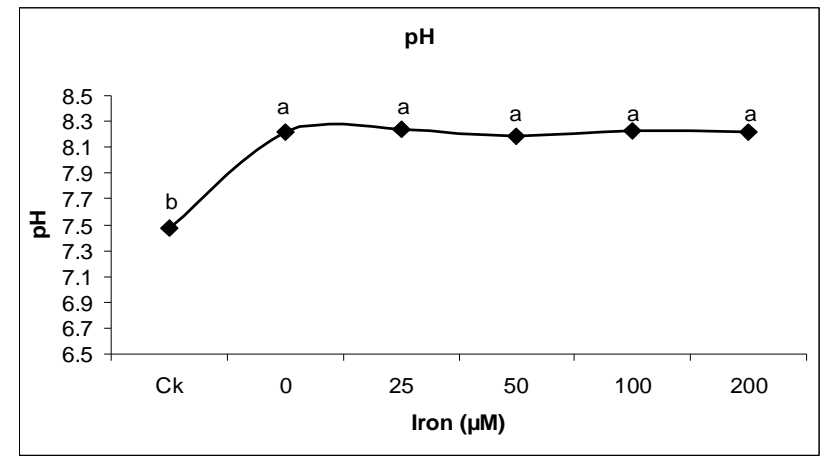

Figure 2 - Effect of different $\mathrm{Fe}^{3+}$ concentrations $\left(0,25,50,100\right.$ and $\left.200 \mu \mathrm{M} \mathrm{Fe}^{3+}\right)$ on final $\mathrm{pH}$ of $P$. polymyxa SQR-21 liquid culture after four days incubation. Means sharing same letter do not differ significantly $(\mathrm{P} \leq 0.05)$.

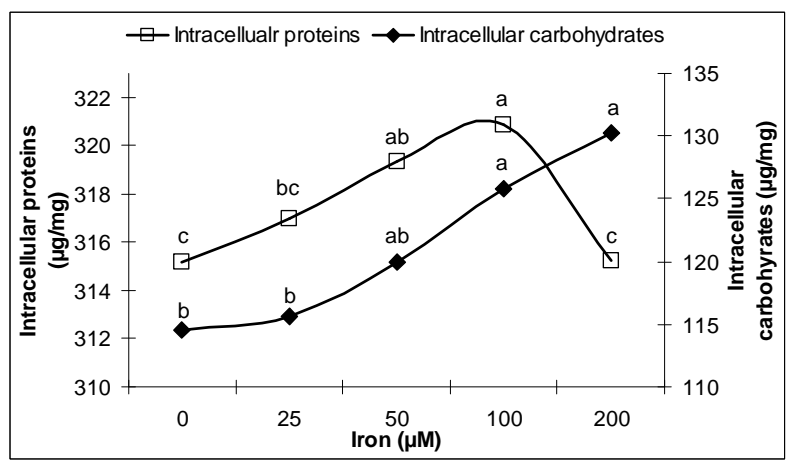

Figure 3 - Effect of different $\mathrm{Fe}^{3+}$ concentrations $\left(0,25,50,100\right.$ and $\left.200 \mu \mathrm{M} \mathrm{Fe}{ }^{3+}\right)$ on intracellular protein and carbohydrate contents of $P$. polymyxa SQR-21 after four days incubation. Means sharing same letter do not differ significantly $(\mathrm{P} \leq 0.05)$.

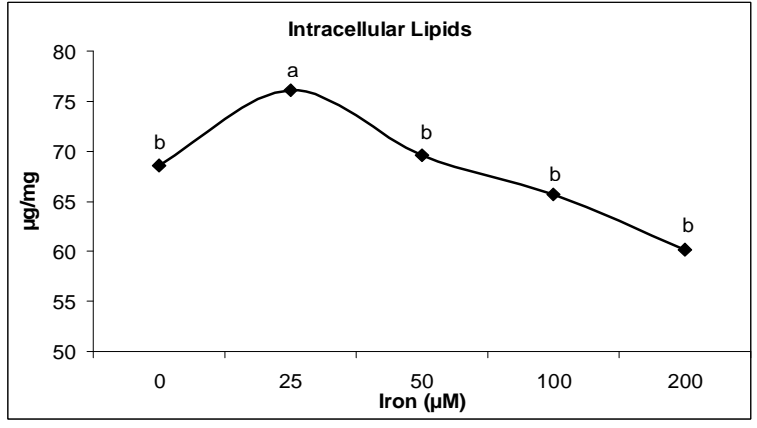

Figure 4 - Effect of different $\mathrm{Fe}^{3+}$ concentrations $\left(0,25,50,100\right.$ and $\left.200 \mu \mathrm{M} \mathrm{Fe}{ }^{3+}\right)$ on intracellular lipid contents of $P$. polymyxa SQR-21 after four days incubation. Means sharing same letter do not differ significantly $(\mathrm{P} \leq 0.05)$. 


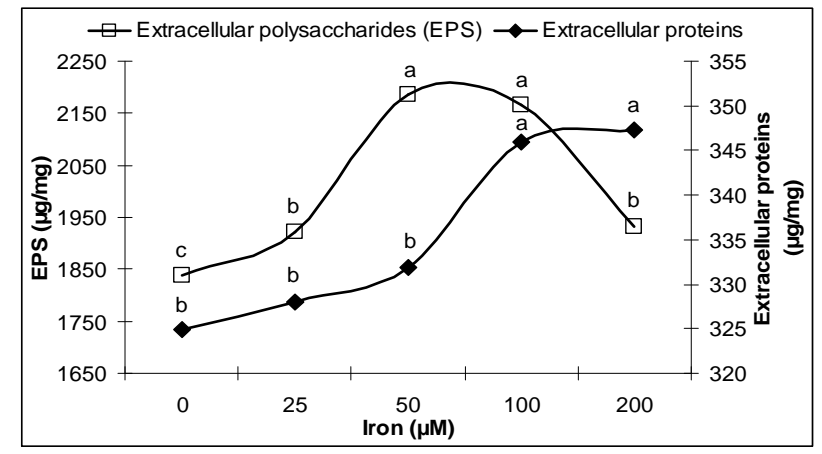

Figure 5 - Effect of different $\mathrm{Fe}^{3+}$ concentrations (0, 25, 50, 100 and $\left.200 \mu \mathrm{M} \mathrm{Fe}^{3+}\right)$ on extracellular protein and polysaccharide contents of $P$. polymyxa SQR-21 after four days incubation. Means sharing same letter do not differ significantly $(\mathrm{P} \leq 0.05)$.

The increase in extracellular protein contents was 1, 2, 6 and 7\% and increase in EPS contents was $1,5,10$ and $14 \%$ over untreated control at 25, 50, 100, $200 \mu \mathrm{M} \mathrm{Fe}^{3+}$, respectively. The protease activity of liquid culture of $P$. polymyxa $(\mathrm{LSD}=3.24)($ Fig. 6) was increased by $6,11,12$ and $13 \%$ while cellulase activity $(\mathrm{LSD}=0.31)$ (Fig. 6) was increased by 4, 9, 15 and $20 \%$ over control at 25, 50, 100, 200 $\mu \mathrm{M} \mathrm{Fe} \mathrm{Fe}^{3+}$, respectively. The results of total RNA contents (Fig. 7) and the relative expression of fusaricidin synthetase gene (fusA) of $P$. polymyxa SQR21(Fig. 7) revealed that total RNA contents $(\mathrm{LSD}=4.37)$ and the relative expression of fusA gene (LSD $=0.22$ ) was increased with the increase in concentration of $\mathrm{Fe}^{3+}$ up to $50 \mu \mathrm{M}$ $\mathrm{Fe}^{3+}$ in the liquid culture. After RNA extraction, DNase treatment was carried out to degrade the genomic DNA and it was confirmed by RTPCR. No DNA contamination was observed after DNase treatment as shown in Fig. 8. Total RNA contents were measured prior to cDNA synthesis. The intensity of amplified fusA gene bands was increased in gene expression with the increase in concentration of $\mathrm{Fe}^{3+}$ in liquid culture up to $50 \mu \mathrm{M} \mathrm{Fe}^{3+}$ (Fig. 8). For RT- and Real Time-PCR, 16S rRNA was used as the positive control. The increase in total RNA contents was 3 and $13 \%$ and increase in the relative expression of fusA gene was 35 and $51 \%$ over untreated control at 25 and $50 \mu \mathrm{M} \mathrm{Fe}^{3+}$, respectively. The decrease in RNA contents was 4 and $23 \%$ while in relative expression of fusA was 29 and $61 \%$ as compared with control at 100 and $200 \mu \mathrm{M} \mathrm{Fe}^{3+}$, respectively.

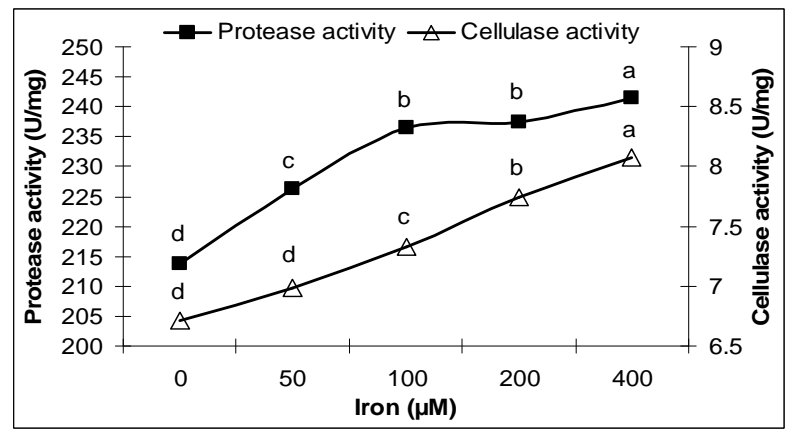

Figure 6 - Effect of different $\mathrm{Fe}^{3+}$ concentrations $\left(0,25,50,100\right.$ and $\left.200 \mu \mathrm{M} \mathrm{Fe}^{3+}\right)$ on protease and cellulase activity in the liquid culture of $P$. polymyxa SQR-21 after four days incubation. Means sharing same letter do not differ significantly $(\mathrm{P} \leq 0.05)$. 


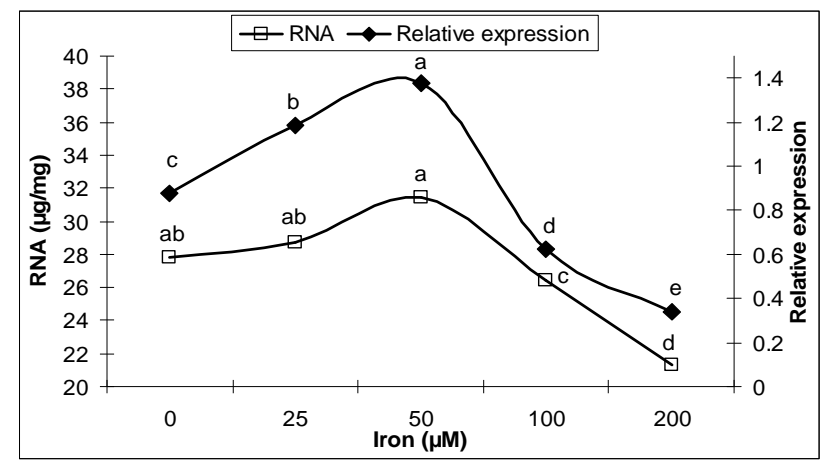

Figure 7 - Effect of different $\mathrm{Fe}^{3+}$ concentrations $\left(0,25,50,100\right.$ and $\left.200 \mu \mathrm{M} \mathrm{Fe}^{3+}\right)$ on total RNA contents and relative expression of fusaricidin synthetase gene (fusA) in P. polymyxa SQR-21. Bars with the same letter are not significantly different at $\mathrm{P} \leq 0.05$.

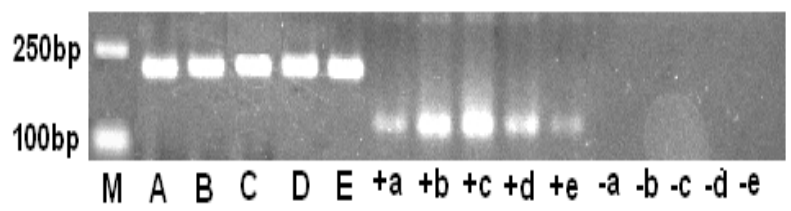

Figure 8 - RT-PCR products originating from cDNA, after extraction of total RNA of $P$. polymyxa SQR-21 grown in submerged culture treated with four concentrations of $\mathrm{Fe}^{3+}(\mathrm{a}=0, \mathrm{~b}=$ $\left.25, \mathrm{c}=50, \mathrm{~d}=100, \mathrm{e}=200 \mu \mathrm{M} \mathrm{Pb}^{+2}\right), \mathrm{M}=\mathrm{DNA}$ marker, A to $\mathrm{E}=$ positive control $16 \mathrm{~S}$ rRNA gene, $+\mathrm{a}$ to $+\mathrm{e}=$ fusA gene $(+\mathrm{RT}),-\mathrm{a}$ to $-\mathrm{e}=$ negative controls for fusA gene $(-$ RT).

\section{DISCUSSION}

Iron is a basic requirement for the normal metabolism of bacterial cell and variations in its concentration in the surrounding environment cause significant effect on usual cell processes and metabolic products. The results of this work revealed that all levels of $\mathrm{Fe}^{3+}$ increased the growth while increase in the antibiotic production was only observed up to $50 \mu \mathrm{M} \mathrm{Fe}{ }^{3+}$. Intra and extracellular protein and carbohydrate contents were increased with the increase in $\mathrm{Fe}^{3+}$ concentration in the liquid culture while intracellular lipid contents were decreased. Total RNA contents and relative expression of fusA gene were increased up to $50 \mu \mathrm{M}$ $\mathrm{Fe}^{3+}$.

The increase in $\mathrm{Fe}^{3+}$ concentration increased the $\mathrm{pH}$ of liquid culture although $P$. polymyxa has been found to produce organic acids such as acetic, formic and oxalic acid (Sharma and Rao, 2001). The acid production by bacteria is associated normally with low nutrient availability as in minimal medium that is low in nutrition. In this work, tryptone broth used had sufficient nutrition for bacterial growth and $\mathrm{Fe}^{3+}$ levels did not influence the acid production by $P$. polymyxa. The slight increase in the growth up to $4 \%$ while increase in the antifungal activity up to 49 and in the relative expression of fusA up to $56 \%$ at $50 \mu \mathrm{M}$ $\mathrm{Fe}^{3+}$ reflected that $\mathrm{Fe}^{3+}$ played a regulatory role, directly or indirectly, in the production of fusaricidin. At higher concentrations, $\mathrm{Fe}^{3+}$ led to a strong decrease in the antibiotic production without affecting slight increase in the bacterial growth, suggesting a specific $\mathrm{Fe}^{3+}$ effect on bacterial secondary metabolism. The mechanisms that how $\mathrm{Fe}^{3+}$ increased the growth and antifungal activity yet has not been elucidated. Different results have been reported regarding the effect of iron on the growth and antibiotic production. For example, Wensinck et al. (1967) reported the iron growth-limiting factor of Pseudomonas aeruginosa using synthetic media solidified with agar. In addition, the elemental Fe had a marked effect on the growth and bulbiformin production by Bacillus subtilis. The optimum requirement of $\mathrm{Fe}$ was $20 \mathrm{ppm}$ for both, the growth and antibiotic activity (Mahmood, 1970). Iron was required for the biosynthesis of cephamycin $\mathrm{C}$ in Streptomyces clavuligerus and higher concentrations 
of iron increased the cephamycin $\mathrm{C}$ production two times. The iron content of the chemically defined medium was shown to be sub-optimal for antibiotic production and the addition of $130 \mu \mathrm{g} / \mathrm{ml}$ iron almost doubled the cephamycin C levels (Rollins et al., 1989). In addition to positive effects of iron on antibiotic production, negative effects have also been reported. Like, Escherichia coli AY25 showed a 95\% decrease in microcin yield when grown in minimal medium containing $10 \mu \mathrm{M}$ iron (high iron) as compared to $0.2 \mu \mathrm{M}$ (low iron). Studies with Escherichia coli mutant deficient in iron-regulated proteins (fur) suggested that factors other than Fur could mediate iron regulation of microcin synthesis (Salomon and Farias, 1994). An iron concentration above 1-2 $\mathrm{mM}$ inhibited tetracycline production in $S$. aureofaciens ATCC 10762 (Bechet and Blondeau, 1998), in contrast with the $0.4 \mathrm{ppb}$ (approximately) of iron required for blocking the tetracycline biosynthesis in the $S$. aureofaciens strain studied by Zenaitis and Cooper (1994). In the present case, different results were obtained as higher levels of iron $\left(>50 \mu \mathrm{M} \mathrm{Fe}^{3+}\right)$ increased the growth and other cellular parameters (except intracellular lipids) but inhibited the antibiotic production, which reflected the concentration dependent specific role of iron on antibiotic production. Whether the effect of iron is direct on genetic or biochemical regulation of fusaricidin or whether their effects are mediated through interactions between these, or other ions. In addition, the location of the regulation by iron remains to be determined and experiments at the molecular level are required to characterize the impact of iron on the fusaricidin production.

In the present study, $\mathrm{Fe}^{3+}$ might be interfering with the secondary metabolism more general to enzymes or cellular processes. The $\mathrm{Fe}^{3+}$ might stimulate the synthesis of the prepeptide or the activation of the appropriate prepeptide maturation enzymes and the transport out of the cell. Recently, $\mathrm{Ca}^{2+}$ binding sites were predicted to be present in NisP peptidase, which cleaved the leader peptide from the precursor nisin (Siezen et al., 1995). Since the precursor was devoid of antibacterial activity (Meer et al. 1993), so $\mathrm{Fe}^{3+}$ might activate the leader peptidase. Lubbe et al. (1984) reported that the complete cephamycin pathway benefited from the higher iron concentration. Three of the enzymes common to the cephalosporin $\mathrm{C}$ and cephamycin $\mathrm{C}$ biosynthetic pathways are known to require iron in their catalytic activities, namely isopenicillin $\mathrm{N}$ synthase (IPNS), deacetoxycephalosporin $\mathrm{C}$ synthase (DAOCS), and deacetoxycephalosporin $\mathrm{C}$ hydroxylase (DAOCH).
The increase in concentration of antibiotic in the medium could be a consequence of the increase in cell wall permeability of SQR-21 promoted by $\mathrm{Fe}^{3+}$, which was in agreement with Petit-Glatron et al. (1993) who studied the capacity of the cell wall to concentrate $\mathrm{Ca}^{2+}$ and proposed that the increased concentration of $\mathrm{Ca}^{2+}$ in the microenvironment of the cell wall could play an important role in the last step of the secretion. Another possibility could be that the $\mathrm{Fe}^{3+}$ activated the enzymes whose activity resulted in a change in the regulatory functions of the cell in favor at low concentration and against at higher concentration of different secondary metabolites, especially fusaricidins. As iron increased the intra and extracellular protein and carbohydrate contents, $\mathrm{Fe}^{3+}$ seemed increasing the enzymes production mainly involved in the fusaricidin synthesis, growth or other activities related to the different cellular processes, which resulted in decrease in the intracellular lipid contents and residual energy was being used for the protein and carbohydrate synthesis. These results were further supported by the increase in protease and cellulase activity with the increase in $\mathrm{Fe}^{3+}$ concentration. The presence of different metal ions such as $\mathrm{Ca}^{2+}, \mathrm{Pb}^{2+}$ and $\mathrm{Mg}^{2+}$ as well as minerals such as iron, aluminium and calcium oxides during the growth influence the types and quantity of polysaccharides, proteins and enzymes secreted by the bacteria (Reed, 1987). The EPS of $P$. polymyxa were composed of varying concentrations of glucose, fructose, galactose, mannose and xylose (Haggag, 2007). The EPS aids in the biological uptake of the metals by chelating and binding them to the cell wall (Deo and Natarajan, 1998). It is preliminary but the first report of the effect of iron on the fusaricidin production. Although $\mathrm{Fe}^{3+}$ exerted negative effects on intracellular lipid contents but it increased the intra and extracellular protein and carbohydrate contents and antibiotic production in the liquid culture. These results provide useful information about the effects of $\mathrm{Fe}^{3+}$ on the overall metabolic processes of $P$. polymyxa mainly fusaricidin production, which could help in the fermentation technology for maximum antibiotic production. Do $\mathrm{Fe}^{3+}$ directly affect the affinity of a protein for its target or substrate? $\mathrm{Is}_{\mathrm{Fe}}^{3+}$ a 'chemical switch' or it encodes specificity? It would be interesting to see what function $\mathrm{Fe}^{3+}$ plays in fusaricidins production and other cellular processes in $P$. polymyxa at different concentrations. 


\section{ACKNOWLEDGEMENTS}

This work was financially supported by the Agricultural Ministry of China (201103004) and National Nature Science Foundation of China (40871126).

\section{RESUMO}

Tipo compostos do fusaricidin do produto das tensões do polymyxa de Paenibacillus que é ativo de encontro a uma variedade larga das bactérias e de fungos gram-positive. $\mathrm{O}$ crescimento, a composição química celular e a produção do fusaricidin datilografam compostos antimicrobial pelo P. o polymyxa SQR-21 foi comparado no caldo de carne do tryptone suplementado com as quatro concentrações $(25, \mu \mathrm{M} 50,100$ e 200$)$ do ferro. Os dados revelaram que o crescimento do $P$. o polymyxa foi aumentado por $3-8 \%$ com o aumento na concentração do íon férrico $\left(\mathrm{Fe}^{3+}\right)$ e o tipo produção do fusaricidin dos compostos foi aumentado $33-49 \%$ somente até 50 pelo $\mu \mathrm{M} \mathrm{Fe} e^{3+}$ quando o nível o mais elevado de $\mathrm{Fe}^{3+}$ era inhibitory. $\mathrm{O}$ aumento na concentração de $\mathrm{Fe}^{3+}$ na cultura líquida aumentou a proteína intracellular $(2 \%)$ e os índices de hidrato de carbono (14\%) e a proteína extracellular $(7 \%)$ e os índices do polysaccharide (18\%) quando os índices intracellular do lipid eram $(11 \%)$ somente até 50 o $\mu \mathrm{M}$ aumentado $\mathrm{Fe}^{3+}$. Além, os efeitos regulatory de $\mathrm{Fe}^{3+}$ foram refletidos também pelo aumento em índices totais do RNA e na expressão relativa do gene do synthetase do fusaricidin (FusA) por 3-13 e por 35-56\% respectivamente, até $50 \mathrm{o} \mu \mathrm{M} \mathrm{Fe}^{3+}$, em seguida que uma diminuição contínua estêve observada.

\section{REFERENCES}

Ash, C., Farrow, J.A.E. and Wallbanks, S. (1991), Phylogenetic heterogeneity of the genus Bacillus revealed by comparative analysis of small subunit-ribosomal RNA sequences. Lett. Appl. Microbiol., 13, 202-206.

Beatty, P.H. and Jensen, S.E. (2002), Paenibacillus polymyxa produces fusaricidin-type antifungal antibiotics active against Leptosphaeria maculans, the causative agent of blackleg disease of canola. Can. J. Microbiol., 48, 159-169.
Bechet, M. and Blondeau, R. (1998), Iron deficiencyinduced tetracycline production in submerged cultures by Streptomyces aureofaciens. J. Appl. Microbiol., 84, 889894.

Bent, E. (2002), Surface colonization of lodgepole pine (Pinus contora Var latifolia) roots by Pseudomonas and Paenibacillus polymyxa under antibiotic conditions. Plant Soil, 2, 187-196.

Berlin, A., Gilkes, N., Kilburn, D., Bura, R., Markov, A. and Skomarovsky, A. (2005), Evaluation of novel fungal cellulase preparations for ability to hydrolyze softwood substrates. Evidence for the role of accessory enzymes. Enzyme Microb. Technol., 37, 175-184.

Boeck, L.D., Hoehn, M.M., Westhead, J.E., Wolter, R.K. and Thomas, D.N. (1975), New Azasteroidal Antifungal Antibiotics from Geotrichum Flavo-Brunneum I. Discovery and Fermentation Studies. J. Antibiot., 28, 95101.

Bradford, M.M. (1976), A rapid and sensitive method for the quantitation of microgram quantities of protein utilizing the principle of protein-dye binding. Analy. Biochem., 72, 248-254.

Deo, N. and Natarajan, K. A. (1998), Studies on interaction of Paenibacillus polymyxa with iron ore minerals in relation to beneficiation. Int. J. Min. Process., 55, 41-60.

Dijksterhuis, J., Sanders, M., Gorris, L.G.M. and Smid, E.J. (1999), Antibiosis plays a role in the context of direct interaction during antagonism of Paenibacillus polymyxa towards Fusarium oxysporum. J. Appl. Microbiol., 86, 13-21.

Dubois, M., Gilles, K.A., Hamilton, J.K., Rebers, P.A. and Smith, F. (1956), Colorimetric method for determination of sugars and related substances. Anal. Chem., 28, 350356.

Espeso, E.A. and Penalva, M.A. (1992), Carbon catabolite repression can account for the temporal pattern of expression of a penicillin biosynthetic gene in Aspergillus nidulans. Mol. Microbiol., 6, 1457-1465.

Haggag, W.M. (2007), Colonization of exopolysaccharideproducing Paenibacillus polymyxa on peanut roots for enhancing resistance against crown rot disease. Afr. J. Biotechnol., 6, 1568-1577.

Ito, M. and Koyama, Y. (1972a), Jolipeptin, a new peptide antibiotic. I. Isolation, physico-chemical and biological characteristics. J. Antibiot., 25, 304-308.

Ito, M. and Koyama, Y. (1972b), Jolipeptin, a new peptide antibiotic. II. The mode of action of jolipeptin. $J$. Antibiot., 25, 309-14.

Izard, J. and Limberger, R.J. (2003), Rapid screening method for quantitation of bacterial cell lipids from whole cells. J. Microbiol. Meth., 55, 411-418.

Kajimura, Y. and Kaneda, M. (1997), Fusaricidins B, C and D, new depsipeptide antibiotics produced by Bacillus polymyxa KT-8, isolation, structure elucidation and biological activity. J. Antibiot., 50, 220-228. 
Leong, S.A. and Expert, D. (1990), Siderophores in plant pathogens interaction. Plant Microbe Interact., 3, 62-83.

Li, J. and Jensen, S. (2008), Nonribosomal biosynthesis of fusaricidins by Paenibacillus polymyxa PKB1 involves direct activation of a d-amino acid. Chem. Biol., 15,118127.

Lubbe, C., Jensen, S.E. and Demain, A.L. (1984), Prevention of phosphate inhibition of cephalosporin synthetases by ferrous ion. FEMS Microbiol. Lett., 25, 7579.

Mahmood, M. (1970), Trace Elements for growth and bulbiformin Production by Bacillus subtilis. J. Appl. Microbiol., 35, 1-5.

Meer van der, J.R., Polman, J., Beerthuyzen, M.M., Siezen, R. J., Kuipers, O.P. and de Vos, W.M. (1993), Characterization of the Lactococcus lactis nisin A operon genes nis $P$, encoding a subtilisin-like serine protease involved in precursor processing, and nisR, encoding a regulatory protein involved in nisin biosynthesis. $J$. Bacteriol., 175, 2578-2588.

Milner, J.L., Raffel, S.J., Lethbridge, B.J. and Handelsman, J. (1995), Culture conditions that influence accumulation of zwittermicin A by Bacillus cereus UW85. Appl. Microbiol. and Biotechnol., 43, 685-691.

Milner, J.L., Laura, S. S., Lee, J.C., He, H., Clardy, J. and Handelsman, J. (1996), Production of Kanosamine by Bacillus cereus UW85. Appl. Environ. Microbiol., 62, 3061-3065.

Mukhtiar, H. (2000), Studies on the Biosynthesis of Antibiotic Rifamycin B by Nocardia Mediternea. $\mathrm{PhD}$ thesis, Islamia University, Bahawalpur.

Petit-Glatron, M.F., Grajcar, L., Munz, A. and Chambert, R. (1993), The contribution of the cell wall to a transmembrane calcium gradient could play a role in Bacillus subtilis protein secretion. Mol. Microbiol., 9, 1097-1106.

Pichard, B., Larue, J.P. and Thouvenot, D. (1995), Gavaserin and saltavalin, new peptide antibiotics produced by Bacillus polymyxa. FEMS Microbiol. Lett., 133, 215-218.

Raza, W., Yang, X., Wu, H., Wang, Y., Xu, Y. and Shen, Q. (2009), Isolation and characterization of fusaricidin type compounds producing strain of Paenibacillus polymyxa SQR-21 active against Fusarium Oxysporum F. sp. nevium. Eur. J. Plant Pathol., 125, 471-483.

Raza, W, Yang W, Shen Q.R. (2008), Paenibacillus polymyxa: Antibiotics, hydrolytic enzymes and hazard assessment. J. Plant Pathol., 90, 403-414.

Reed, G. (1987), Industrial Microbiology, 4th ed. CBS Publishers, New Delhi.
Rollins, M.J., Jensen, S.E. and Westlake, D.W.S. (1989), Regulation of antibiotic production by iron and oxygen during defined medium fermentations of Streptomyces clavuligerus. Appl. Microbiol. Biotechnol., 31, 390-396.

Ryu, C.M., Kim, J., Choi, O., Kim, S.H. and Park, C.S. (2006), Improvement of biological control capacity of Paenibacillus polymyxa E681 by seed pelleting on sesame. Biol. Cont., 39, 282-289.

Salomon, R.A. and Farias, R.N. (1994), Influence of iron on microcin 25 production. FEMS Microbiol. Lett., 121, 2759.

Sharma, P.K. and Rao, K.H. (2001), Role of a heterotrophic Paenibacillus polymyxa bacteria in the bioflotation of some sulfide minerals. In- Mineral Biotechnology, ed. S.K. Kawatra, and K.A. Natarajan. Society for Mining, Metallurgy and Exploration, pp. 67.

Siezen, R.J., Rollema, H.S., Kuipers, O.P. and Vos de, W.M. (1995), Homology modeling of the Lactococcus lactis leader peptidase $N i s P$ and its interaction with the precursor of the lantibiotic nisin. Protein Eng., 8, 117125 .

Timmuska, S., Nicandera, B., Granhallb, U. and Tillberga, E. (1999), Cytokinin production by Paenibacillus polymyxa, Soil Biol. Biochem., 31, 1847-1852.

Tseng, T.C. and Mount, M.S. (1974), Toxicity of endopolygalacturonate, phosphate and protease to potato and cucumber tissue. Phytopathol., 64, 229-236.

Weinberg, E.D. (1970), Biosynthesis of secondary metabolites: role of trace metals. Adv. Microb. Physiol., 4, $1-44$.

Wensinck, F., van Dalen, A., Wedema, M. (1967), Iridescent material and the effect of iron on its production by Pseudomonas aeruginosa. Antonie van Leeuwenhoek, 33, 73-86.

Zenaitis, M.G. and Cooper, D.G. (1994), Antibiotic production by Streptomyces aureofaciens using selfcycling fermentation. Biotechnol. Bioeng., 44, 1331-1336.

Zhang, S., Raza, W. and Yang, X. (2008), Control of Fusarium wilt disease of cucumber plants with the application of a bioorganic fertilizer. Biol. Fertil. Soils, 44, 1073-1080. 